(C) Ю.Ф. Кушта, Л.М. Когут, Р.В. Яремкевич, 2018

УДК 617 - 089. 152/. 154

\title{
Можливі небезпеки та ускладнення хірургії damage control на сучасному етапі, шляхи їх корекції
}

\author{
Ю.Ф. Кушта, Л.М. Когут, Р.В. Яремкевич \\ urijkushta@gmail.com
}

\section{Національний медичний університет імені Данила Галицького, медичний факультет, кафедра загальної хірургії, Львів}

Вступ. На сьогодні хірургія damage control представляє собою актуальний та своєрідний напрям сучасної медичної науки та практичної медицини.

Мета дослідження. Ознайомлення з можливими небезпеками та ускладненнями, які можуть розвиватися у категорії важко травмованих пацієнтів 3 пошкодженнями внутрішніх органів і подальшою кровотечою з них. Водночас у роботі вказується перелік невідкладних заходів, які необхідно реалізувати у таких випадках.

Матеріали та методи дослідження. Матеріалом дослідження були травмовані особи, які перенесли важкі комбіновані, поєднані, також множинні пошкодження з кровотечою з внутрішніх органів. Серед них значний відсоток становили особи, які отримали вогнепальні поранення, в тому числі черевної порожнини, під час бойових дій. У роботі був застосований аналітичний метод дослідження. Однією з небезпек хірургії damage control $\epsilon$ гіпотермія. Вона призводить до серцевої аритмії, зменшення серцевого викиду, також пригнічує імунну систему. Тривала гіпоперфузія травмованих осіб зумовлює анаеробний метаболізм та розвиток лактатного ацидозу. Травматичні пошкодження спричиняють порушення балансу зсідання та протизсідання крові. При цьому розвивається коагулопатія. У значній кількості випадків вищевказані небезпеки виникають водночас. Такий симптомокомплекс називається «летальна тріада». Найважчим ускладненням хірургії damage control $\epsilon$ виникнення абдомінального компартментсиндрому. У віддаленому післяопераційному періоді констатовано випадки евентерації та нагноєння операційних ран. Отже, вчасне діагностування та корекція «летальної тріади» призводить до збільшення частоти виживання важко травмованих осіб; при виявленні небезпек та ускладнень хірургії damage control всі зусилля повинні бути спрямовані на відновлення фізіологічних процесів у пацієнтів.

Ключові слова: гіпотермія, коагулопатія, метаболічний ацидоз, «летальна тріада», абдомінальний компартментсиндром, інфікування, корекція, короткотривала операція, декомпресія, фізіологічні функції, летальність, виживання

Possible dangers and complications of damage control surgery for today; the means of their correction Kushta Yu.F., Kohut L.M., Yaremkevych R.V.

Danylo Halytsky National Medical University, Medical Faculty, General Surgery Unit, Lviv

Abstract

For today damage control surgery is an actual and original direction of the modern medical science and practical medicine. The purpose of our research is representation of possible dangers and complications, that can develop in the group of seriously injured patients with damages of internal organs and further bleeding from these organs. In the same time in our work indicates the list of urgent measures, that necessary to realize in such cases. The material of research were injured persons after severe combined, associated and multiple damages with bleeding from internal organs. Among them considerable rate were persons, who got gunshort wounds, including abdominal cavity, during military actions. In our work used analytic method of investigation. One of danger of damage control surgery is hypothermia. It leads to cardiac arrhythmia, decreasing of cardiac output, supresses immune system also. Long term hypoperfusion of injured persons provokes anaerobic metabolism and development of lactate acidosis. Traumatic damages causing disorders of blood coagulation and fibrinolysis balance. In such cases develops coagulopathy. In considerable amount of cases an enumerated dangers appear simultaneously. Such symptom complex named as tethal triad". The most severe complication of damage control surgery is appearance of abdominal compartment - syndrome. In remote postoperative period stated a cases of abdominal burst and suppuration of operational wounds. Thus, timely diagnosing and correction of tethal triad" leads to increasing of survival frequency of severe injured persons; during revealing of dangers and complications of damage control surgery all efforts should be directed on restoration of physiologic processes in the patients.

Key words: hypothermia, coagulopathy, metabolic acidosis, tethal triad", abdominal compartment-syndrome, contamination, correction, abbreviated operation, decompression, physiological functions, mortality, survival

Вступ. На сьогодні хірургія damage control - це актуальний та своєрідний напрям сучасної медичної науки та практичної медицини [1]. Принципи damage control були запозичені у військових. Під час Другої світової війни відбувалися битви у Тихому океані між Японією та Сполученими Штатами Америки. Значна кількість кораблів після пошкоджень могла деякий час утримуватися на поверхні води. Моряки уражених суден вживали першочергові заходи у дуже короткі терміни, щоб відтя- гнути їх до місць постійного базування. Тільки після цього розпочинався капітальний ремонт кораблів. Завдяки такій тактиці було врятовано багато дороговартісних військових суден. Дану методику почали успішно використовувати хірурги при наданні першої допомоги та лікуванні травмованих пацієнтів.

Мета дослідження. На сьогодні широкому колу медиків відомі принципи проведення хірургії damage control, проте остаточно не зрозумілі фізіо- 
логічні, біохімічні, метаболітичні процеси, які відбуваються в організмі пацієнтів 3 важкими пошкодженнями органів черевної порожнини. Метою нашого дослідження є вивчення небезпек і ускладнень, які можуть розвиватися у даної категорії потерпілих. Важливою ланкою роботи є представлення комплексу невідкладних лікувальних заходів при виникненні цих небезпечних станів.

Матеріали та методи. Матеріалом дослідження були травмовані особи, які перенесли важкі комбіновані, поєднані, також множинні пошкодження. В основному це пацієнти молодого, працездатного віку, переважно чоловічої статі. Серед них значний відсоток становили особи, які отримали вогнепальні поранення, в тому числі черевної порожнини, під час бойових дій. 3 метою дотримання державної, також військової таємниці, у нашій роботі не вказана загальна кількість хворих, ïх розподіл за гендерним і віковим принципом. У статті був застосований аналітичний метод дослідження.

Результати досліджень та їх обговорення. Однією з небезпек хірургіï damage control $\epsilon$ гіпотермія [2]. Вона $є$ наслідком важких виснажливих пошкоджень організму та наступних спроб їх відновлення. Важкі кровотечі призводять до гіпоперфузії тканин і зменшення їх постачання киснем, відповідно до зниження температури тіла та нездатності підтримувати необхідну температуру (тепло) [3]. Гіпотермія набуває важливого клінічного значення, коли температура стає нижчою за $36{ }^{\circ} \mathrm{C}$ протягом більше як 4 години. У пацієнтів 3 множинними, важкими пошкодженнями вона зумовлює несприятливий прогноз, а температура, нижча за $32{ }^{\circ} \mathrm{C}$ асоціюється зі 100\% летальністю. Гіпотермія призводить до серцевої аритмії, зниження серцевого викиду, збільшення системного судинного опору та зміщення вліво кривої кисневої дисоціації. Окрім цього, вона пригнічує імунну систему [4].

Тривала гіпоперфузія важко травмованих осіб призводить до анаеробного метаболізму та подальшого розвитку лактатного ацидозу. Вона може пригнічувати скоротливість міокарда і, відповідно, також спричиняє зниження серцевого викиду. Розвиток метаболічного ацидозу зумовлює продовження кровотечі за рахунок інактивації факторів коагуляції $[5,6]$.

Окрім цього, травматичні пошкодження спричиняють порушення балансу систем зсідання та протизсідання (фібринолізу) крові. При цьому розвивається коагулопатія. Вона супроводжується дисфункцією тромбоцитів. Коагулопатії також притаманна генералізована кровотеча з ран, серозних оболонок, з ділянок, де розташовані судини, країв шкіри [7].

У значній кількості випадків вищевказані небезпеки розвиваються водночас. У таких ситуаціях даний симптомокомплекс називається «летальна тріада». Виникнення «летальної тріади» призво- дить до суттєвого фізіологічного виснаження пацієнтів [3,8].

За нашими даними, найважчим ускладненням хірургіï damage control $€$ виникнення абдомінального компартмент-синдрому (АКС) [1,9]. Він супроводжується вісцеральним набряком, утворенням гематоми і подальшою тампонадою. Виникає компресія дихальних шляхів, неадекватна вентиляція легень, гіпоксія 3 олігурією та анурією. В подальшому розвивається ниркова та легенева недостатність. Розтягнення черевної порожнини та збільшення ії̈ в розмірах призводить до компресійного ателектазу та вентиляційно-перфузійної невідповідності. Збільшений внутрішньочеревний тиск зменшує венозний відтік, що зумовлює зниження серцевого викиду та посилення резистенції судин. Також уражується центральна нервова система за рахунок збільшення внутрішньочерепного тиску. Це, в свою чергу, призводить до підвищення центрального венозного тиску [3,4].

У пацієнтів даної категорії існує високий ризик виникнення ускладнень і у віддаленому післяопераційному періоді. Констатовано декілька випадків нагноєння післяопераційної рани, евентерації $[5,8]$. Ці ускладнення виникають тому, що у черевній порожнині концентрується велика кількість збудників інфекції, як аеобних, так і анаеробних. Окрім цього, згідно з літературними даними, можливий розвиток раневого сепсису, неспроможності швів рани $[5,8]$. Описані випадки утворень нориць, виникнення пошкоджень підшлункової залози, товстих кишок [1].

При виникненні гіпотермії ми намагалися виконати лапаротомію у найкоротші терміни [9]. Окрім цього, з пацієнтів знімали вологий одяг, одягали у сухий, теплий. 3 метою зігрівання травмованих осіб застосовувалися спеціальні терморегуляційні покривала. Необхідна допомога надавалася пацієнтам у теплих приміщеннях. Інфузійна терапія проводилася підігрітими розчинами. Всім пацієнтам вдалося підняти температуру тіла до $37{ }^{\circ} \mathrm{C}$ впродовж 3-4 годин після переведення їх у палату інтенсивної терапії - після первинного операційного втручання. Виникнення коагулопатії попереджувалося трансфузією великих доз еритроцитарної маси, свіжозамороженої плазми, кріопреципітату - під контролем протромбінового індексу та часу $[6,7,10]$. Завдяки належному зігріванню пацієнта та проведенню лікування у палаті інтенсивної терапії чи реанімації, у нашій групі хворих метаболічний ацидоз не розвивався. Виконання оксигенотерапії забезпечувало в пацієнтів трансформацію анаеробного метаболізму в напрямі до аеробного [4].

У випадках виникнення абдомінального компартмент-синдрому у прооперованих пацієнтів основним завданням було забезпечити надійну та негайну декомпресію черевної порожнини $[1,9]$. У ситуаціях нагноєння післяопераційних ран і евентерації були реалізовані традиційні загальнохірургічні підходи для їх усунення $[8,9,11]$. 
Висновки. Вчасне діагностування та корекція «летальної тріади» приводять до збільшення частоти виживання важко травмованих осіб.
При виявленні небезпек і ускладнень хірургії damage control всі зусилля повинні бути спрямовані на відновлення фізіологічних процесів у пацієнтів.

Інформація про конфлікт інтересів. Автори заявляють про відсутність конфлікту інтересів при виконанні наукового дослідження та підготовці даної статті.

Інформація про фінансування. Автори повідомляють, що під час виконання даної роботи не отримували фінансової підтримки у вигляді грантів, обладнання, лікарських препаратів. Автори також гарантують про відсутність нагород в будь-якій формі від фірм - виробників лікарських препаратів, медичного обладнання та матеріалів, у тому числі від конкурентів.

Особистий внесок кожного автора у виконання роботи:

Кушта Ю.Ф. - розробка концепції і дизайну дослідження, збір матеріалу, аналіз отриманих даних;

Когут Л.М. - аналіз отриманих даних, підготовка тексту;

Яремкевич P.В. - аналіз отриманих даних, підготовка тексту, редагування.

\section{Список використаної літератури}

1. Zarutskyi YL, Trutiak IR. Etapne likuvannia postrazhdalyh za tazhkoi zakrytoi pojednanoi abdominalnoi travmy. Klinicheskaya hirurgia. 2013;10:48-51. [In Ukrainian].

2. Buchenmaier C, Nahoney PF. Combat anesthesia: the 24 hours. Textbook of military medicine. Buchenmaier C, Nahoney PF, editors. Borden Institute Fort Sam Houston: Texas; 2015. 977 p.

3. Tisherman SA, Forsythe RM. Trauma intensive care. New York; Oxford University Press; 2013. 335 p.

4. Scher CS. Anesthesia for trauma. New evidence and new challenges. New York: Springer; 2014. 461 p.

5. Harwood-Nuss' Clinical practice of emergency medicine. Wolfson AB, editor. 6th ed. Philadelphia: Wolters Kluwer; 2015. $1651 \mathrm{p}$.

6. Marcucci CE, Schoettker P. Perioperative hemostasis. Coagulation for anesthesiologists. Heidelberg: Springer; $2015.456 \mathrm{p}$.

7. Khan S, Davenport R, Reza I, et al. Damage control resuscitation using blood component therapy in standard doses has a limited effect on coagulopathy during trauma hemorrhage. Intensive Care Med. 2015;4(12):239-47.

8. Bailey SA, Morrison JJ, Rasmussen TE. Military trauma system in Afghanistan: lessons civil systems? Curr Opin Crit Care. 2013 Dec;19(6):569-77.

9. Kushta YF, Kohut LM, Roniak RP. Osoblyvosti vykonannia damage control pry vognepalnyh poranenniah organiv cherevnoi porozhnyny. Klinicheskaya hirurgia. 2016;10.3(893):14-15. [In Ukrainian].

10. Hasan A. Handbook of blood gas / acid- base interpretation. London: Springer; 2013. 345 p.

11. Kushta YF, Kushta NV. Persha dopomoga pry minno - vybuhovyh poranenniah. Klinicheskaya hirurgia. 2015;11.2:101. [In Ukrainian].

Стаття надійшла до редакції: 9.01.2018 р. 